\title{
COMPARATIVE STUDY IN DEVELOPING COFFEE SHOP ENTERPRISES AT MALANG REGENCY AND MATARAM CITY WEST NUSA TENGGARA
}

\author{
By \\ Ramdah Radjab ${ }^{1}$, Dewa Made Dirga ${ }^{2}$, Ainul Yakin ${ }^{3}$ \\ 1,2,3 Program Studi Diploma 3 Tata Hidang Politeknik Pariwisata Lombok \\ Email: ${ }^{1}$ Ramdah@ppl.ac.id, ${ }^{2}$ dewa.dirga@ppl.ac.id, ${ }^{3}$ ainul.yakin@ppl.ac.id
}

\begin{tabular}{l}
\hline \hline Article Info \\
\hline Article History: \\
Received:12-10-21 \\
Revised : 19-11-21 \\
Accepted: 26-11-2021 \\
\\
\hline Keywords: \\
Coffee shop Enterprises, \\
Malang Regency and Mataram \\
City
\end{tabular}

CorrespondingAuthor:

Ramdah Radjab

Program Studi Diploma 3 Tata Hidang Politeknik Pariwisata Lombok

Email: Ramdah@ppl.ac.id

\begin{abstract}
Developing Micro, Small and Medium Enterprises (MSME) is a strategic step to increase and strengthen the basis of economic life for most Indonesian people, primarily through providing employment and diminishing poverty rate. Coffee is one of the world's commodities that brought Indonesia to fame. In the coffee industry, a cup of coffee has been named a cup of Java. this research will be dedicated to developing coffee shops in Ampenan Old Town by comparing the strategy for developing coffee shops in Malang Regency, particularly in the DAU area as one of the coffee shops centers in the city. The analysis technique applied in this research is the descriptive qualitative analysis, which systematically, factually, and accurately describes or illustrates a phenomenon related to the studied phenomenon. The strategy of Malang Regency Government by synergizing all policies from entire official institutions and governmental elements is quite neat and sound, including with East Java Province, effected properly on the policies integration from crossservice. In Malang Regency, researchers found creativity and efforts made by MSMEs in dealing with the Pandemic, from regulating operational hours, opening and closing outlets, making packaging products, in collaborating with OJOL (Public Porter), During the Pandemic, there is no right or perfect strategy to overcome it.
\end{abstract}

Thisisan open accessarticleundertheCC BY-SAlicense.

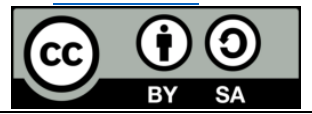

\section{INTRODUCTION}

Developing Micro, Small and Medium Enterprises (MSME) is a strategic step to increase and strengthen the basis of economic life for most Indonesian people, primarily through providing employment and diminishing poverty rate. For supporting the effort to reduce poverty and provide jobs, it is conducted a provision for supporting and facilitating the attempt to develop a productive economy of informal/micro-sized, especially in low-economic families and/or in underdeveloped regions and poverty areas (Arisandi et al. 2014).

The development of micro-scale business is aimed to increase business capacity and business management skills, and at the same time to increase their business protection and certainty so that it becomes a self-reliant business unit, sustainable and ready to expand and compete. MSME empowerment is also aimed to support in creating job opportunities and increasing export, such as through improving the certainty to do business and legal certainty, development of incentive system to establish technological-based new ventures and/or export-oriented and also increasing access and export market expansion for Cooperative and MSME products (Kemenkop UMKM, 2014). Through this MSME, it is expected can establish economic sovereignty that prioritizes people's prosperity in which the focus in this research is the development of the Coffee Shops in Ampenan Old Town - Mataram - West Nusa Tenggara.

Coffee is one of the world's commodities that brought Indonesia to fame. In the coffee industry, a cup of coffee has been named a cup of Java. Since the Dutch colonial era, Indonesia (especially Java) was known as a coffee producer with the finest savor in the world. Today, Indonesia is the producer and also, at the same time as the critical consumer of the coffee commodity. As the producer, Indonesia ranks fourth after Brazil, Vietnam, and 
Colombia, and as the consumer, the country is in the seventh position (International Coffee Organization (ICO), 2017). For Indonesian people, generally, coffee as a drink has become a part of daily life, particularly for adults, and currently, adolescents and children also like it. ICO (2015) reveals that the growth of coffee consumers is increasing rapidly in Indonesia, more significant than the world's growth, $8 \%$ for Indonesian coffee consumers, while the world's coffee consumer only reaches $6 \%$. The association of exporters and the Indonesian Coffee Industry (AEKI) mentions that national coffee consumption growth increases from 0.8 kilograms per capita to 1.3 kilograms per capita (Indonesian Ministry of Industry, 2014).

Parallel with coffee industry development, the world's coffee IKM business opportunity also impacted the Indonesian coffee industry. In Indonesia, the coffee industry has recently increased in the downstream industry, as reflected in the widespread of coffee shops and cafés everywhere. As Indonesian plantation product is also essential, coffee ranks sixth after oil palm, rubber, sugar, tea, and cocoa. Indonesian position as the consumer is critical because the increase in domestic demand can decrease its supply available for export to the world market. The important trends of the coffee industry were summed up in the 2016 ICO annual review.

First, in terms of production, the availability of robusta coffee will get pressure because the weather has affected coffee production in Vietnam and Indonesia. In the long-term, the world's consumption may keep on increasing, slightly below 2\% annually. However, in East and Southeast Asia, consumption grows above 5\%. It is predicted that the world's total consumption is increasing if the production can keep up. If the production keeps on left behind or under pressure, it is predicted that the price will go up. The current global challenge of the coffee industry is the production deficit, as in the last decade (2005-2016). The consumption has exceeded the production capability, although it has not created a shortage in the supply because the coffee is still available and surplus in several years, in 2012-2013 and 2013-2014. Coffee IKM's business opportunity has decreased since 2010-2011, and the lowest was in 2015-2016. The coffee industry started to rise up after January 2016. The Indicator price of the ICO composite reached the lowest point, 106,74 cents USD/lb, in January, before it recovered and then reached the highest level by 151,69 cents in July 2016 (Ministry of Agriculture, 2013).

The opportunity of coffee MSME product is extensive to be marketed at the International level to increase the nation's and local producer's economy throughout Indonesia. The progress of coffee business development is significant so that in the future, it should be a trend and as beverages product which become the primary option for tourists visiting West Nusatenggara. Coffee products as beverages products have a unique taste from one area to another. All people can drink this product with many types of coffee, and its taste can become a favorite drink option for coffee lovers. Concerning the NTB Governor's Regulation Number 2 of 2015 regarding Halal Tourism, Coffee needs to be labeled and developed, including the types of coffee used as a garnish or as flavor seasoning in many food and beverages.

Ampenan, as a Gate of Lombok had become the center of economy in Lombok Island in which every export product of eastern Indonesia was stored and transported using ships from Ampenan since 1775. It was established as the first harbormaster warehouse by British nationality in Ampenan. Data shows that in 1855-1856, many foreign ships docked to carry crops from Ampenan to outside Lombok, even to Singapore and Hongkong (ARRA, NHM 1856-51). This fact shows that MSME in the Old Town of Ampenan, particularly in Pelabuhan Street (currently Pabean Street), at the time, has become the part of the center of the economy for the local people and West Nusatenggara society. However, lately, these good things have experienced a significant drawback, both before and particularly when the Covid-19 Pandemic shocked the world. Therefore, this research will be dedicated to developing coffee shops in Ampenan Old Town by comparing the strategy for developing coffee shops in Malang Regency, particularly in the DAU area as one of the coffee shops centers in the city. Hence, this research is entitled: Comparative Study: Developing MSME Coffee shop in Malang Regency and Mataram City West Nusa Tenggara.

1. The formulation of problems in this research is: How are the strategies of Malang Regency Government and Mataram Municipal Government in developing coffee shop MSME on the Pandemic situation?

2. What is the effort of the coffee shop MSME entrepreneur in Malang Renceny and Mataram City to increase value in the Pandemic situation?

3. What is the strategy in coffee shop MSME of Malang Regency as Comparison can be applied to coffee shop MSME in Ampenan to increase value in Pandemic situation?

\section{The Purpose of this Research are:}

1. To determine the strategy of Malang Regency Government and Mataram Municipal Government to develop coffee shop MSME in Pandemic situation.

2. To determine the effort of coffee shop MSME in Malang Regency and Mataram City to increase value in Pandemic situation 
International Journal of Social Science (IJSS)

Vol.1 Issue.4 December 2021, pp: 505-512

ISSN: 2798-3463 (Printed) | 2798-4079 (Online)

DOI: https://doi.org/10.53625/ijss.v1i4.983

3. To discuss the strategy of coffee shop MSME in Malang Regency as the comparison applicable in coffee shop MSME in Ampenan to increase value in Pandemic situation?

Practically, this research can be utilized by the stakeholders to develop food and beverages culinary and MSME activist who focuses on developing coffee shop business in Lombok, particularly in Ampenan, Pabean St. (now-Yos Sudarso St, ) - Mataram.

Theoretically, the benefit of this research can be taken as a reference by the government being the manual to develop MSME in NTB, particularly coffee beverages activists, and as a reference for future research.

\section{Scope of the Research}

This research was carried out in Malang Regency, one of the coffee shop destinations in Indonesia. It is expected to become a comparative study for being the model of MSME in Mataram City determined based on the priority scale of MSME development in Northern Mataram City, i.e., Ampenan Old Town. The locus selection of this research is focused on the following reasons:

1. It is the area that has a unique characteristic in developing coffee MSME for ages

2. It is the historical area since the Majapahit era, Karang Asem era, until the Dutch Colonial era, and the first international harbor in Lombok Island.

3. The research was conducted for five months, from March until August 2021.

This research output is as Entrepreneurial learning module and Barista Art in Lombok Polytechnic of Tourism and as input for Mataram Municipal Government in developing Local MSME in Ampenan - Mataram - NTB.

\section{LITERATURE REVIEW}

\section{Definition of MSME}

According to the MSME Act of the Republic of Indonesia, Number 20 of 2008 Article 1 states that Micro Business is a productive venture that belongs to individual and/or private entities meeting the criteria of Micro Business as stipulated in this Act. Small Business is a productive economic business established self-reliance, conducted by individual or legal entities which not part of companies nor branch of companies owned, managed, or being a direct or indirect part of Medium Business or Large Business meeting the criteria of Small Business stipulated in this Act. Medium business is a productive economic business established independently, conducted by individual or legal entities which are not part of companies nor branch of enterprises owned, managed, or being direct or indirect part with Small Business or Large Business with a net worth or annual sales amount income as stipulated in this Act. As for MSME, the criteria for Micro Business are a. having a maximum net worth of 50,000,000.00 IDR (fifty million rupiahs) excluding land and building for business; or 7) b. and having maximum annual sales income of 300,000,000.00 IDR (three hundred million rupiahs). 2. Small Business Criteria is as follows: a. having net worth more than 50,000,000.00 IDR (fifty million rupiahs) to a maximum of 500,000,000.00 IDR (five hundred million rupiahs) exclude land and building for business; or b. having annual sales income of more than $300,000,000.00$ IDR (three hundred million rupiahs) to a maximum of 2,500,000,000.00 IDR (two billion and five hundred million rupiahs). 3. Medium Business Criteria is as follows: a. having net worth more than 500,000,000.00 IDR (five hundred million rupiahs) to a maximum of 10,000,000,000.00 (ten billion rupiahs) exclude land and building for business; or $\mathrm{b}$. having annual sales income of more than 2,500,000,000.00 IDR (two billion and five hundred million rupiahs) to a maximum of 50,000,000,000.00 IDR (fifty billion rupiahs).

\section{Coffee Shop.}

A coffee shop is a small business that belongs to a family in a tavern, stall, small shop, or simple restaurant. The term "warung" can be found in Indonesia and Malaysia. The shop is one of the micro-businesses and an essential part of Indonesian people's daily lives. Meanwhile, the food shops generally display simple food, such as fried bananas and coffee. Besides selling Indonesian food, some stalls vend Asian food (continental) and western food, such as fried rice and noodles, commonly found in stalls. The term "warung' also refers to shop or tavern (Wikipedia free encyclopedia (Anonim).2015.https://id.Wikipedia.org/wiki/warung. Accessed on 25 February 2021 at 14.22 WIB) and become the basis for the term of the coffee shop, which was adopted from the word "shop" preceded with the word "coffee." A shop can be treated as a small or individual coffee shop managed solely to fulfill the owner's daily life and only employs its family members.

A modern shop will pay more attention to interior design displayed for the youth to look catchy for taking a picture and browsing social media. Meanwhile, traditional coffee shops more prioritize on its unique flavors. The modern coffee shop provides many kinds of coffee, starting from robusta to arabica and other high-quality coffee seeds. We go back again to the differences between modern and traditional coffee shops. The traditional coffee shop does not use wifi, but the modern coffee shop would not be complete without it (Sriwardiningsih \& Notoatmojo, 2019). 


\section{Strategy for Developing MSME}

In the strategy for developing MSME, there are four stages underwent by MSME, e.g., start-up stage, growth stage, expansion stage, and finally going overseas stage. The successful MSME model development implemented in Singapore are these four stages of MSME building. Nonetheless, Indonesia has not had a comprehensive model that can be applied as the building model for the medium term and long term (Tiktik Sartika and Soejoedono, 2002 in Setiawan, 2004). According to Tiktik Sartika and Soejoedono (2002), the strategy for developing MSME are:

1. Business Partnership is a business cooperation relationship among various parties that is synergically, voluntarily, and based on mutual principle, support each other, and mutually beneficial, accompanied by MSME coaching and building by large enterprises.

2. MSME capital. Generally, MSME capital is frail, and both are viewed from the start-up capital and access to the long-term capital for investment. For mobilizing the start-up capital, it is necessary to mix with three aspects, i.e., financial aid, technical assistance, and surety program, while for increasing access to capital, it needs to optimize the role of bank and microfinance agency MSME. Meanwhile, MSME absorption on banks' credit is still low. More than $80 \%$ of banks' credit is concentrated in the corporate segment. Meanwhile, the credit portion for MSME is only between $15-21$ percent of the total bank's credit (Statistic Economy of Indonesian Finance, May 2004). For optimizing the range of credit provision to MSME, it has been developed credit scheme with Integrated Partnership Program, for instance, StateOwned Companies Partnership and Community Development Program (PKBL), Partnership with BPR Program, and Cooperative and Association, and Program Credit.

3. Venture Capital, generally the MSME does not like or understand the procedure or conditions required by Banking institutions. Conversely, the banking institution sometimes makes their inferior perception regarding MSME potential. This perception distorts MSME funding. Therefore, venture capital can be an alternative source for MSME funding.

\section{Definition of Promotion}

According to Basu Swastha and Handoko in Ferny (2016), promotion is the long-term incentive to encourage purchasing or selling a product or service. According to Stanson in Angipora in Bulaeng in Ferny (2016)), promotion is the combination of the best strategy from advertisement variable, personal sales, and other promotion tools, in which all are planned to achieve the sales program.

\subsection{Previous Research}

\section{Juanda (2015)}

The research result is: (1) the income of coffee shop entrepreneurs in Kuala subdistrict Nagan Raya Regency in 2014 fluctuates, disparate in each month, the income is uncertain, sometimes goes up and sometimes goes down yet, there are some get fixed income. Their income was determined by customers who came to buy, primarily the customer came in off-days or weekends, so their income is increasing. (2) the total income earned by the respondent of coffee shop entrepreneurs is roughly around 64,056,000 per year.

\section{Randy Irvan Pratama (2019)}

This research result reveals that the coffee shop business is very efficient to increase one's income, and in the long term, it would decrease unemployment rates, particularly in Gresik City.

\section{Radjab, Ramdah (2019)}

Journal Internasional with a theme ICOBOROT 2019 (ISBN: 978-94-6252-879-6) entitled "Halal Tourism: Unique, Simple and Worth It!". This research focuses on improving product quality and attraction with Halal branding and labeling. It is also related to the merchant's problems, marketing tips, and consumer behavior. The scope includes the realm of uniqueness and originality, simplicity or modesty, and meaningfulness of a product.

\section{Radjab, Ramdah; Dirga, Dewa Made; Arcana, I Nyoman, et al. (2021)}

From the result of group research of 2019, it is published a writing booked in Kamala, Bali Tourism Polytechnic, ISBN: 978-602-51521-4-6 entitled, "Pelayanan makanan dan minuman pada pesta pernikahan masyarakat adat di Indonesia sebagai daya tarik pariwisata berbasis masyarakat" in page $169-208$. This study focuses on serving banquets in traditional wedding ceremonies in three locations, Sade customary village community - Lombok, Baduy ethnic community - Banten, and Tomohok customary community in Toba Lake - North Sumatera tourist attractions. This study does not compare the way of serving banquets in the three customary communities in apple to apple, however, from the perspective of each uniqueness. This distinction leads to the final objective, the availability of guidance on eating in the Archipelago as one of the table manners a la Indonesia.

\section{Ainul Yakin (2019 and 2020)}

This research discusses the theme and strategy of developing a coffee shop MSME which can be applied in coffee shop MSME in Pabean Street Ampenan Lombok with a comparative study on similar business in Malang Regency. 
International Journal of Social Science (IJSS)

Vol.1 Issue.4 December 2021, pp: 505-512

ISSN: 2798-3463 (Printed) | 2798-4079 (Online)

3. RESEARCH METHOD

Conceptual Framewor

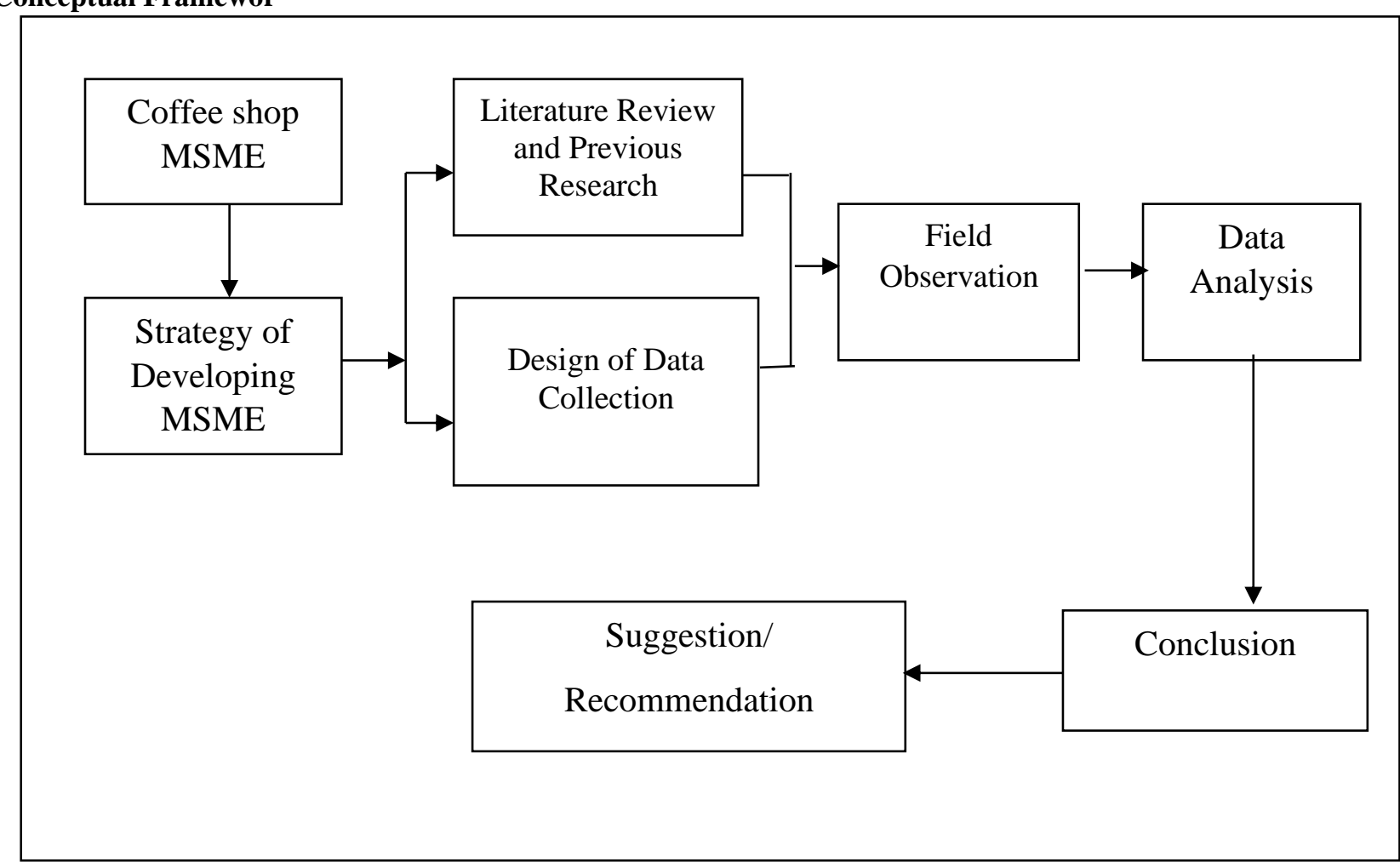

\section{Data types and sources}

The data source in this research is primary data and secondary data. The primary data is collected and information from primary sources, e.g., 1). Coffee Lovers, 2). Coffee Merchants, 3). From Local Government. Meanwhile, the secondary data are the research supporting data derived from the internet, print media, and electronic media relevant to the research title and theme.

\section{Research Location and Time}

This research is in Ampenan, Pabean Street, Mataram City (currently Yos Sudarso Street), DAU Village, Pujon Subdistrict, Malang Regency, East Java Province. The research period was from April 2021 until August 2021, more or less about 5 (five) months.

\section{Research Focus}

1. The strategy of Malang Regency Government and Mataram Municipal Government to develop coffee shop MSME in Pandemic situation.

2. The effort of MSME coffee shop entrepreneurs in Malang Regency and Mataram City to increase value in the Pandemic situation.

3. The strategy of MSME coffee shop in Malang Regency as the comparison can be applied to coffee shop MSME in Ampenan to increase value in Pandemic situation.

\section{Data Collection Technique}

Adapun teknik pengumpulan data dalam penilitian ini yaitu dengan cara: Observasi, Informan, Hal yang dianggap primer Studi literatur

\section{Data Analysis}

The analysis technique applied in this research is the descriptive qualitative analysis, which systematically, factually, and accurately describes or illustrates a phenomenon related to the studied phenomenon (Kusmayadi and Sugiarto, 2000:8). 


\section{RESULT AND DISCUSSION}

\section{Malang Regency Government and Mataram Municipal Government Policy during Pandemic and post- pandemic anticipation.}

The government would do related to the relevant issues with current momentum concerning Covid-19. Indeed, all policies are adjusted with central government policy regarding Covid-19 problems, so the government's most manageable steps are by addressing some issues that occurred, such as vaccination, and then Green Zone, continued by conducting PPKM. These policies make regional government cannot do other things or do otherwise because they, somehow, must do Synergy with the regulations stipulated by the central government. Subsequently, it is related to business progress in West Nusa Tenggara, particularly Lombok and Mataram City. How Covid has had a massive impact on the social economy and tourism, but one still being optimistic. Some MSME businesses can survive in this situation, especially discussing coffee, they cannot discuss the downstream level at the coffee shop, but in any case, the downstream is supported by the farmer level. Farmers in this situation can still survive; maybe it is coincidental. Coffee farmers are in the current season before harvest; even some types of coffee that have been harvested are local coffee, usually Arabica Robusta, while Tugusari Malangsari followed. Now farmers are in optimism to welcome the coffee harvest (MS-Mataram 6)

\section{The effort of Coffee shop MSME entrepreneurs in Malang Regency and Mataram City to increase value in a} pandemic situation

Researchers argue that the merchants/coffee shop managers in Malang Regency have enough works to increase creativity, product, training, and various efforts to deal with the pandemic situation. However, in Mataram city, there are many obstacles expressed by the informants, so that their efforts are not well-recorded by entrepreneurs and coffee shop managers in Mataram city to overcome this Pandemic. Consequently, their coffee shops survive and maybe earn profits to drive their business operation

The strategy of MSME coffee shop in Malang Regency as the comparison that can be applied to coffee shop MSME in Ampenan to increase value in Pandemic situation

From the various data described above, the strategy adopted in Mataram City can be taken into account as what has been conducted by the HAAGA KOPI owner, who temporarily closed at the beginning of the Pandemic to manage financial strategies and observe market developments. Nonetheless, some businesses continue to operate. After the situation seems to improve immediately, the others will also be opened by addressing high standards and anticipation of the pandemic transmission. Additionally, HAAGA KOPI also continues to make product innovations and training so that during the Pandemic, businesses can continue to roll out and be financially healthy, although according to the HAAGA KOPI owner, it is not easy, and there are many obstacles, but of course, the strategy can be implemented by the shop managers conforming to the conditions and situation of Mataram City,

Furthermore, the Kelentung Coffee shop has never closed its coffee shop even during the Pandemic, which previously they could sell coffee around 50-200 Cups, but during the Pandemic, it was only 10-20 Cups per day. Furthermore, this situation is used by the shop owner to continue to update the product and evaluate the service, in which they have five employees from the family so that employee salaries can be appropriately discussed. For Mataram city, this can be used as a mirror. When starting a business, one can use their circle as employees before looking for professionals after the shop is more advanced.

There is also a company called DAMPIT coffee, this company also has a coffee shop and a coffee export business, but during the Pandemic, they also suffered a downfall both in the café and in coffee exports. However, the strategy taken is to package their coffee products according to customer standards; as a result, the coffee packaging becomes diverse. DAMPIT Coffee Shop has a coffee product known as coffee beer. It sounds like alcoholic BEER, but this is an innovative product from primary coffee material without any alcohol. This interesting creativity can be applied in coffee companies around Mataram.

In this case, the writers argue that from the various data resulting from FGDs, interviews, and observations to the locations in Malang and Mataram Regencies, studies on the development of coffee shops and coffee products must continue in the future because the creativity of coffee products and the culture of drinking coffee continue to grow in Indonesia and even internationally.

\section{CONCLUSION}

1. The strategy of Malang Regency Government by synergizing all policies from entire official institutions and governmental elements is quite neat and sound, including with East Java Province, effected properly on the policies integration from cross-service. While in Mataram Regional government has not been able to integrate agencies to execute central government policies, both between offices in Mataram city and with the NTB 
International Journal of Social Science (IJSS)

Vol.1 Issue.4 December 2021, pp: 505-512

ISSN: 2798-3463 (Printed) | 2798-4079 (Online)

DOI: https://doi.org/10.53625/ijss.v1i4.983

provincial government, especially the agencies related to MSME coffee shops such as the Cooperative, Industry, and Tourism Office.

2. In Malang Regency, researchers found creativity and efforts made by MSMEs in dealing with the Pandemic, from regulating operational hours, opening and closing outlets, making packaging products, to collaborating with OJOL; eventually, some MSMEs in Mataram City have started to make the same efforts.

3. During the Pandemic, there is no right or perfect strategy to overcome it, and it also occurs in Malang city; opening and closing shops, reducing employees, and tightening on expenses are the most effective strategies to date. However, in Malang Regency, researchers have also found product innovation strategies and their creation quite successful, such as (HAAGA KOPI \& KOPI DAMPIT).

\section{SUGGESTION}

1. For Mataram Municipal Government, it is recommended to coordinate all agencies so that they are well connected as in Malang Regency, especially during the Pandemic. Consequently, MSMEs in Mataram City can have firm, structured and measurable policy guidelines.

2. It is suggested that MSME coffee shops' efforts in Mataram City in dealing with the pandemic situation should be creative and increase innovation as some entrepreneurs in Malang Regency.

3. Strategies to increase value during the Pandemic, it should be done by entrepreneurs/MSMEs in Mataram City, especially on Jalan Pabean, Ampenan Old Town to study in Malang Regency, from strategies to control finances, strategies to reach the market, to the product innovation that will be served to customers.

\section{REFERENCES}

[1] Arisandi. 2014. Efektivitas penerapan e-commerce dalam perkembangan usaha kecil menengahdi sentra industry sandal dan sepatu wedoro kabupaten sidoarjo Publshed by e-journal.stiedewantara.ac.id

[2] Febriansyah. 2019. Pengembangan Usaha UMKM Kedai Kopi Abang Kecamatan Pulogadung Dengan Metode Business Model Canvas. Published by LPMP Imperium Journal homepage: https://ejournal.imperiuminstitute.org/index.php/BERDAYA: Jurnal Pendidikan dan Pengabdian Kepada Masyarakat Vol 1, No.2, 2019: 89 - 96

[3] Julianus, Daniel. 2018. Makna Gaya Hidup Minum Kopi Di Cofee Shop Kalangan Anak Muda Penikmat Kopi Di Provokatif. Bachelor Thesis thesis, Universitas Multimedia Nusantara. https://kc.umn.ac.id/5851/

[4] Ministry of cooperatives, data on micro, small and medium enterprises development (umkm). https://kemenkopukm.go.id

[5] Moleong, J. Lexy. 2019. Metodologi Penelitian Kualitatif. PT. Remaja Rosda Karya Bandung.

[6] Nasir, Moh. 2011. Metodologi Penelitian. Ghalia Indonesia, Jakarta.

[7] Regional Regulation of West Nusa Tenggara Province Number 2 of 2016 concerning Halal Tourism.

[8] Regional Regulation of West Nusa Tenggara Province Number 51 of 2015 concerning Halal Tour.

[9] Radjab, Ramdah. 2019. Halal tourism. Unique, simple, and worth it!. The Atlantis Press, Paris. ISBN: 97894-6252-879-6 https://doi.org/10.2991/icoborot-18.2019.11

[10] Radjab, Ramdah; Dirga, Made Dewa, et al. 2019. Begibung sebagai atraksi wisata pada upacara adat masyarakat desa Bayan Kabupaten Lombok Utara dan Pegringsingan Tenganan Candidasa Kabupaten Karangasem Bali. Penelitian Kelompok Prodi Tata Hidang, Poltekpar Lombok, Praya-Nusa Tenggara Barat.

[11] Radjab, Ramdah; Dirga, Made Dewa; Arcana, I Nyoman, et al. 2020. Pelayanan makanan dan minuman pada pesta pernikahan masyarakat adat sebagai daya Tarik pariwisata berbasis masyarakat. Journal Gastronomi $\begin{array}{llllllll}\text { Indonesia, } & \text { Vol. } & 8 & \text { No. } 2020 .\end{array}$ https://ejournal.ppb.ac.id/index.php/jgi/article/view/555/425

[12] Radjab, Ramdah; Dirga, Made Dewa; Arcana, I Nyoman, et al. 2021. Pelayanan makanan dan minuman pada pesta pernikahan masyarakat adat di Indonesia sebagai daya tarik pariwisata berbasis masyarakat. Kamala. PPB, Bali. ISBN: 978-602-51521-4-6

[13] Raliby, Oesman dan Retno Rusdjijati. 2016. Analisis Potensi Unggulan Daerah Kabupaten Magelang Menuju One Vilage One Product. Seminar Nasional IENACO. Page 769-777.

[14] Setiawan, A.H. 2004. Fleksibilitas Strategi Pengembangan Usaha Kecil Dan Menengah: Virsamika Franconia Vol. 1 No. 2 / December 2004: 118 - 124

[15] Sriwardiningsih, E dan Notoatmodjo, B. 2019. Budaya, Kepribadian, Sosial, Psikologi Berpengaruh pada Perilaku Pemilihan Lokasi Café pada Konsumen Penikmat Kopi Jurnal Ekonomi, Manajemen dan Perbankan (Journal of Economics, Management and Banking). Vol. 5 No. 1 (2019). http://journal.ibs.ac.id/index.php/JEMP/issue/view/29 
[16] Sudiyato, S; Widayati, S dan Kresna, D.M. 2012. Perilaku konsumen penikmat kopi tubruk dan kopi instan. $\begin{array}{llllllll}\text { Jurnal Sosial Ekonomi Pertanian (JSEP). } & \text { Vol. } 6 & \text { No. } & 3 & \text { (2012). }\end{array}$ http://jurnal.unej.ac.id/index.php/JSEP/article/view/805

[17] Sugiono. 2015. Memahami Penelitian Kualitatif. CV. Alfabeta Bandung.

[18] UMKMKalbar.Id.2020: Kafe Jawi.JL. Rais A. Rachman, Sungai Jawi No. 229 Pontianak Call dan Wa +628596030 0842

[19] Yakin, A. 2020. Halal Tourism Marketing Strategies on Authentic Lombok Culture: A Preliminary Analysis. Cordova Journal/Journal Kajian Bahasa dan Budaya. UIN Mataram.

[20] Yakin, A. dan Fajriasanti, R. 2019. Potensi Label Pariwisata Halal pada Restoran dan Kafe di Kawasan Ekonomi Khusus (KEK) di Mandalika Lombok Tengah. Journal of Lombok Tourism Archipelago Volume 1 Nomor 1, Oktober, 2019. Hal 23-30 Homepage: http://ojs.ppl.ac.id/index.php/JoTA 